\title{
Educators' working conditions in a day care centre on ownership of a non-profit organization
}

\author{
Bianca Kusma ${ }^{1,2^{*}}$, Stefanie Mache ${ }^{1,3}$, David Quarcoo ${ }^{1}$, Albert Nienhaus ${ }^{4}$ and David A Groneberg ${ }^{1}$
}

\begin{abstract}
Background: Working conditions of nursery school teachers have not been scrutinized thoroughly in scientific research. Only a few studies have so far examined work-load and strain in this profession. Preferably, subjective perceptions should be corroborated by data that can be quantified more objectively and accurately. The aim of the present observational field study was to evaluate pedagogical staffs' workflow.
\end{abstract}

Methods: In 2009 eleven educators in a day care centre were observed throughout three complete workdays. A total of 250 working hours were recorded.

Results: An educators' workday lasted on average 07:46:59 h $(S D=01: 01: 10 \mathrm{~h})$. Within this time span, an average of 02:20:46 h (30.14\%, SD =00:28:07 h) were spent on caring, 01:44:18 h on playing (22.33\%, SD =00:54:12 h), 00:49:37 $\mathrm{h}$ on educational work (10.62\%, SD $=00: 40: 09)$, and only 00:05:38 $\mathrm{h}$ on individual child contact (1.21\%, SD $=00: 04: 58 \mathrm{~h}$ ).

Conclusion: For the first time, educators' workflow in day care centres was studied in real time. Some of the educators' self-reported problems were corroborated. The results of this study form a basis upon which further investigations can be built and measures can be developed for an overall improvement of child care.

Keywords: educator, working conditions, task analysis, workload, real-time observation

\section{Introduction}

The PISA study (Programme for International Student Assessment) of the OECD comparing education among 15-year-olds in more than 30 countries showed that scholar performance of German pupils ranked low in the list of participating countries. The study also found that children who went to kindergarten or pre-school education achieve better results. Therefore more attention has been paid to day care centres as first socializing institutions [1]. Working conditions of pedagogical staff are not very well studied. Nevertheless this profession is subject to several psychosocial requirements [2]. Stress in this job is mainly caused by an interaction of minor strains which sum up in their negative effect [3]. Beside caring and educational duties pedagogical staff is confronted with additional tasks from a changed market situation (e.g. increased competition, certifications for

\footnotetext{
* Correspondence: kusma@em.uni-frankfurt.de

'Institute for Occupational, Social and Environmental Medicine, Theodor-

Stern-Kai 7, 60590 Frankfurt am Main, Germany

Full list of author information is available at the end of the article
}

quality control, independent management). Educators are often overtaxed by these tasks. As a consequence of these job conditions nursery school teachers are susceptible to develop complaints like backache, nervousness, headaches and stress or components of job burn-out and mental satiation [4]

Research questions on how these demands have an effect on the work ability and the health status of employees have also not been examined. Only capable, healthy and content personal is able to give a good care for children [5]. Therefore it is important not only to maintain the health of pedagogical staff in day care centres but also to promote it.

A general strike of German nursery school teachers in 2009 expressed their dissatisfaction with current working conditions. Educators complained about: shortage of staff [1], unfavourable respectively long working hours and difficulties in contact with parents [2]. Roughly 25.000 nursery school teachers struggled for better working conditions, improved health protection and higher salaries.

\section{() Biomed Central}

(c) 2011 Kusma et al; licensee BioMed Central Ltd. This is an Open Access article distributed under the terms of the Creative Commons Attribution License (http://creativecommons.org/licenses/by/2.0), which permits unrestricted use, distribution, and reproduction in any medium, provided the original work is properly cited. 
Nursery school teachers criticise in particular size of the group and an increased amount of paperwork. Research showed that a combination of both comes at the cost of direct child contact. In addition, educators have the feeling that they are not able to advance and support all children sufficiently $[1,6,7]$.

A few questionnaire studies exist on work-load and strain in this profession but they are mainly based on self-reports. At present objective data is not available $[1,8]$. Nevertheless relying only on subjective statements of nursery school teachers might increase the risk of bias problems [9]. Keeping that fact in mind, an objective work analysis was conducted to collect precise time data of educators' work tasks. The overall aim of the monitoring was evaluate pedagogical staffs' workflow, identify sources of stress, and to provide an informative basis for the development of approaches for prevention.

\section{Subjects and Methods}

\section{Setting and participating educators}

Data of the BASE study (Bidirectional Assessment of Stress, job satisfaction and work ability of Educators in day care centres [10]) was collected from 10/09 to 12/ 09. Prior to the beginning of the monitoring a written request was sent to the management of a randomly selected day care centre on ownership of a non-profit organization in Berlin. After receiving departmental approval, educators were invited to participate in the study on a voluntary basis.

Inclusion criteria were as follows: (1) the participants have to hold a degree as early childhood educator or an equal value in training and (2) they have to work at least 6 hours (h) a workday. Of the 28 employed educators, 11 were female educators, who met the eligibility criteria, agreed to participate in the study.

\section{Data collection method}

Pedagogical staffs' workflow was observed and registered in real time as described in detail in Mache (2010) [11]. A trained observer shadowed an educator recording each performed task with an Ultra Mobile PC (UMPC; designed software Samsung Q1; Samsung Electronics GmbH, Schwalbach, Germany) [12] and a specially designed software.

Thirteen task categories with 38 sub-categories were defined in order to describe the majority of job tasks educators carry out both sequentially and simultaneously during a typical work day (see Table 1). By using this program information could be gained about main and secondary activities and quantitative information about direct child contact. All activities (main and secondary) were recorded in units of time [12].

\section{Content validity}

The process of developing the taxonomy started with a literature review and interviews with experienced educational specialists (Table 1). Subsequently an observation phase of two workdays was carried out to approve the content validity of the task categories, after which the taxonomy was modified. The final version of the task list was generated and then implemented to code tasks performed by participating pedagogical staff.

\section{Interobserver reliability}

An interobserver reliability testing took place. Two trained observers recorded tasks of the same nursery school teacher simultaneously but independently over a period of $7 \mathrm{~h}$. An interobserver agreement of $86 \%$ was achieved.

\section{Data collection procedure}

Participants were monitored a complete work day by a trained observer. Data collection took place only on weekdays (Monday to Friday). Each of the 11 educators was accompanied throughout three different work shifts. During the observational period all working activities of the subjects were captured in real time.

To minimize the Hawthorne effect (possibility that educators change their performance in response to being observed) the observer stood at a distance of at least $3 \mathrm{~m}$ from the educator and was not allowed to talk to her/him.

\section{Data Analysis}

All collected data were entered into a Microsoft Excel $2007^{\circledR}$ spreadsheet for analysis. Descriptive statistics were calculated by using SPSS software package for social sciences, Version 18.0.

\section{Results}

\section{Demographic characteristics of participants}

All eleven participants were female with an average age of 36.3 years $(\mathrm{SD}=7.4$ years, range $25-47$ years $)$. The overwhelming majority of participants hold a degree as early childhood educator (90.9\%), only one hold a university degree in education. On average, the pedagogical staff hat 12.2 years of work experience $(\mathrm{SD}=10.3$ years).

\section{Activities performed by educators}

A total of 33 work days were monitored. This corresponds to 250 working hours. An average work day lasted 07:46:59 $\mathrm{h}(\mathrm{SD}=01: 01: 10 \mathrm{~h})$. During this time a mean of 00:27:28 h (SD =00:12:13 h) were reserved for breaks. The five most frequent performed tasks were: play $(01: 44: 18 \mathrm{~h} ; \mathrm{SD}=00: 54: 12 \mathrm{~h})$, meals $(01: 14: 27 \mathrm{~h}$; 00:17:17 h), walking (01:13:41 h; SD = 00:37:23 h), educational work $(00: 49: 37 \mathrm{~h} ; \mathrm{SD}=00: 40: 09 \mathrm{~h})$ and child 
Table 1 Tasks performed by educators by category

\begin{tabular}{ll}
\hline Category & Description of activity \\
\hline Documentation and administrative & $\begin{array}{l}\text { Writing observation forms, documentation assessment for schools, keep a diary of the progress of the } \\
\text { tasks }\end{array}$ \\
$\begin{array}{l}\text { Children } \\
\text { Child care }\end{array}$ & $\begin{array}{l}\text { Croviding of food, feeding of smaller children } \\
\text { Meals }\end{array}$ \\
Afternoon nap & Supervision of the afternoon nap \\
Contact to parents & Welcoming, parents' evenings \\
Educational work & Singing, sportive activities, preparation und conducting of small experiments \\
Cleaning & Cleansing of rooms and toys, plants and animal husbandry \\
Continuing education/Supervision & Attendance at continuing education, supervision of work \\
Individual contact & Settle a dispute, console a child, welcoming of a child, individual support \\
Walking & Walking around between tasks (e.g. inside and outside of the day care centre, excursion) \\
Rest period: Break & Time of recovery (e.g. lunch) \\
Playing & Playing with children, surveillance of playing children \\
Internal Communication/meetings & Conversation with other educators or other staff, telephone calls \\
\hline
\end{tabular}

care (00:40:55 h; SD =00:13:25). The average times and percentages of each main work-related activity performed by educators are summarised in table 2 .

\section{Caring}

The main tasks of a regular workday $(02: 20: 46 \mathrm{~h}, \mathrm{SD}=$ 00:28:07 h) can be assigned to the category "caring" (e.g. child care, meals and supervision of the afternoon nap). A nursery school teacher spent an average of 01:14:27 $\mathrm{h}$ $(\mathrm{SD}=00: 17: 17 \mathrm{~h})$ a day on preparing food and feeding smaller children. The mean daily duration of child care (e.g. changing nappies, helping children to change clothes) amounted to 00:40:55 h ( $\mathrm{SD}=00: 13: 25 \mathrm{~h})$. Additionally $25 \mathrm{~min}(\mathrm{SD}=00: 25: 50 \mathrm{~h}$ ) were dedicated to supervision of the afternoon nap.

\section{Playing}

Another substantial block of time was allotted to the category "playing". During the study period nursery school teachers spent a total of $57: 21: 48 \mathrm{~h}$ on playing with children, which correspondents to $22.33 \%$ of all work activities. On average each educator spent 01:44:18 $\mathrm{h}(\mathrm{SD}=00: 54: 12 \mathrm{~h})$ daily on this task.

\section{Educational duties}

On the whole, ten per cent of the time recorded was spent on educational work (23:17:16 h). This correspondents to 00:49:37 $\mathrm{h}$ daily $(\mathrm{SD}=00: 40: 09 \mathrm{~h})$. Activities in this category mostly involved singing, dancing and other sportive activities as well as preparation and conducting small experiments.

Table 2 Average times for main activities performed by educators

\begin{tabular}{|c|c|c|c|c|}
\hline Categories & $\begin{array}{c}\text { Sum main } \\
\text { activity } \\
\text { (hh:mm:ss) }\end{array}$ & $\begin{array}{c}\text { Average } \\
\text { time main activity } \\
\text { (hh:mm:ss) }\end{array}$ & $\begin{array}{c}\text { SD main } \\
\text { activity } \\
\text { (hh:mm:ss) }\end{array}$ & Percentage \\
\hline Documentation and administrative tasks & 07:00:43 & $00: 12: 45$ & 00:10:13 & 2.73 \\
\hline Child care & $22: 30: 16$ & 00:40:55 & $00: 13: 25$ & 8.76 \\
\hline Meals & 40:56:55 & 01:14:57 & $00: 17: 17$ & 15.94 \\
\hline Afternoon nap & 13:58:14 & $00: 25: 24$ & $00: 25: 50$ & 5.44 \\
\hline Contact to parents & 03:39:24 & 00:06:39 & 00:10:15 & 1.42 \\
\hline Educational work & $23: 17: 16$ & $00: 49: 37$ & 00:40:09 & 10.62 \\
\hline Cleaning & 05:44:59 & $00: 10: 27$ & 00:07:44 & 2.24 \\
\hline Continuing education/Supervision & 00:15:01 & 00:00:27 & 00:01:29 & 0.10 \\
\hline Individual contact & 03:05:54 & 00:05:38 & 00:04:58 & 1.21 \\
\hline Walking & $38: 31: 39$ & 01:13:41 & $00: 37: 23$ & 15.78 \\
\hline Breaks & 15:06:34 & $00: 27: 28$ & $00: 12: 13$ & 5.88 \\
\hline Playing & $57: 21: 48$ & 01:44:18 & $00: 54: 12$ & 22.33 \\
\hline Communication & 19:21:55 & $00: 35: 13$ & $00: 28: 56$ & 7.54 \\
\hline
\end{tabular}




\section{Internal communication and meetings}

On average each nursery school teacher dedicated 00:35:13 h per day ( $\mathrm{SD}=00: 28: 56 \mathrm{~h}$ ) to meetings and internal communication. In addition 01:34:53 h (SD = 00:35:14 h) were spent on internal communication and meetings as simultaneous tasks.

During the study period only one educator took part in continuing education $(\mathrm{M}=00: 00: 27 \mathrm{~h}, \mathrm{SD}=00: 01: 29 \mathrm{~h})$.

\section{Administrative task}

Each educator spent average time of 00:12:45 h $(\mathrm{SD}=$ 00:10:13 h) on documentation duties. If simultaneously performed tasks were included an additional 00:07:15 h $(\mathrm{SD}=00: 03: 55 \mathrm{~h})$ per day were dedicated to administrative tasks. These activities principally comprised writing observation forms and took up an average of 00:06:48 $\mathrm{h}$ $(\mathrm{SD}=00: 07: 28 \mathrm{~h})$.

\section{Individual contact with children and communication with parents}

During the study period educators spent a total of 03:05:54 h on individual contact to children. This corresponds to an average time of 00:05:38 h $(\mathrm{SD}=00: 04: 58$ h) per day. This task includes the sum of time allotted for settling of disputes consoling of a child as well as welcoming a child and individual support with educational tasks. Additionally 01:02:25 h $(\mathrm{SD}=00: 35: 39 \mathrm{~h})$ were shared between individual contact with children and other tasks.

It was observed that nursery school teachers spent 00:06:39 $\mathrm{h}(\mathrm{SD}=00: 10: 15 \mathrm{~h})$ per day on communication with parents. These six min of communication included welcoming and parents' evenings.

\section{Additional tasks}

The participating nursery school teachers spent an average of 01:13:41 $\mathrm{h}$ walking between tasks $(\mathrm{SD}=00: 37: 23 \mathrm{~h})$.

Another 00:10:27 h (SD = 00:07:44 h) were allotted for cleansing of rooms and toys as well as plants and animal husbandry.

\section{Multitasking}

Educators spent a total of 118:14:58 h (47.14\%) performing two or more activities at the same time during the study period. This corresponds to 03:35:00 h (SD = 00:50:36 h) on an average shift. Table 3 gives a summary of the different simultaneous activities performed by pedagogical staff. The most common task was "surveillance of playing children" while simultaneously "talking to another educator"

\section{Changing activities}

Changes in activities were measured to obtain additional information about educators work flow. On average participants performed 24 different tasks per working hour $(\mathrm{SD}=8.74)$. The busiest hour of the work day was the first where 37 tasks were performed.

The average frequency of job task rotations that educators do within single working hours are shown in Figure 1.

\section{Discussion}

The current study analysed work activities of educators. To our knowledge, no computer-based real time studies do exist on working conditions in day care centres.

Our study revealed several important findings. Consistently with educators' perception relatively little time was allotted to individual contact to a child. This contact enables cognition of child's resources and abilities [13]. But a successful advancement of children requires enough time to build a relationship [14]. Therefore a reduction of the size of the group is needed.

A stable relationship between nursery school educator and child assists development, educational and learning processes [14]. This finding might be explained by the attachment theory. Close connections affect social behaviour and also self-perception, possibilities to interact as well as learning skills of a person. Attachment, education and literacy are a precondition, that a child can grow up in a holistic and positive manner [15]. However educator-child-relation is strongly affected by institution. Former studies showed that strain and workload have an influence on the relationships to children. Connections get formalised, which has negative consequences for children and educators [16].

Moreover, only a small amount of time was spent on contact to parents. Parental involvement is an important factor to mediate between educational institution and family structures. It is seen as a basic support of pedagogical work in the day care centre [17-19]. A successful exchange between nursery school teacher and parents could be beneficial for educational process of all relevant children. Former studies showed that family-supportive measures are particularly successful if parents and educators cooperate [20]. The use of manifold experiences of pedagogical staff and parents is meaningful for child's development. Furthermore a positive relationship between educator and parents is essential for a valuable child care. A parent should have the possibility to talk about any possible concern with the nursery school teacher, even more because educator are those - adjacent to physicians - who call parents' attention most frequently to developmental disorders of their children [21]. In this connection contact to parents is important with regard to preventive measures.

In opposition to nursery school teachers' reports in the current study only a small amount of time was devoted to documentation duties during study period. 
Table 3 Average times for simultaneous activities performed by educators

\begin{tabular}{|c|c|c|c|c|}
\hline Categories & $\begin{array}{l}\text { Sum simultaneous } \\
\text { activity } \\
\text { (hh:mm:ss) }\end{array}$ & $\begin{array}{l}\text { Average time } \\
\text { simultaneous activity } \\
\text { (hh:mm:ss) }\end{array}$ & $\begin{array}{l}\text { SD simultaneous } \\
\text { Activity } \\
\text { (hh:mm:ss) }\end{array}$ & Percentage \\
\hline Documentation and administrative tasks & 03:59:24 & 00:07:15 & 00:03:55 & 3.37 \\
\hline Child care & 03:21:25 & 00:06:06 & 00:06:40 & 2.84 \\
\hline Meals & $04: 22: 36$ & 00:07:57 & 00:04:13 & 3.70 \\
\hline Afternoon nap & 00:01:56 & 00:00:04 & 00:00:12 & 0.00 \\
\hline Contact to parents & 04:06:57 & 00:07:29 & 00:05:53 & 3.48 \\
\hline Educational work & 02:26:02 & 00:04:26 & 00:04:26 & 2.06 \\
\hline Cleaning & 02:03:12 & 00:03:44 & 00:02:04 & 1.74 \\
\hline Continuing education/Supervision & 00:01:34 & 00:00:03 & 00:00:09 & 0.02 \\
\hline Individual contact & 34:19:59 & 01:02:25 & 00:35:39 & 29.03 \\
\hline Walking & 01:13:17 & 00:02:13 & 00:02:40 & 1.03 \\
\hline Breaks & 00:00:00 & 00:00:04 & 00:00:13 & 0.03 \\
\hline Playing & 10:07:42 & $00: 18: 25$ & $00: 19: 26$ & 8.57 \\
\hline Internal Communication/meetings & $52: 10: 54$ & $01: 34: 53$ & $00: 35: 14$ & 44.13 \\
\hline
\end{tabular}

One reason therefore may be that educators have no time to fulfil these duties on the job. Research data confirm that pedagogical staff often completes these tasks during leisure time [22].

A source of stress is the high number of simultaneously performed tasks. One key result of the present study was the magnitude of multitasking in the workplace. As the principal reason for multitasking is reduction of time-pressure [23], this finding corroborates nursery school teachers' self-reports $[1,6,24,25]$. The demanding work environment compel nursery school teachers to perform two or more activities at the same time, although multitasking causes cognitive overload and has been found to be associated with reduced performance at work $[26,27]$. Moreover sequentially performed tasks last as long as simultaneously executed tasks [28]. Besides a reduced work performance multitasking may also affect the quality in child care.

\section{Limitations}

Our study is subject to certain methodological limitations. First, our sample only consists of female nursery

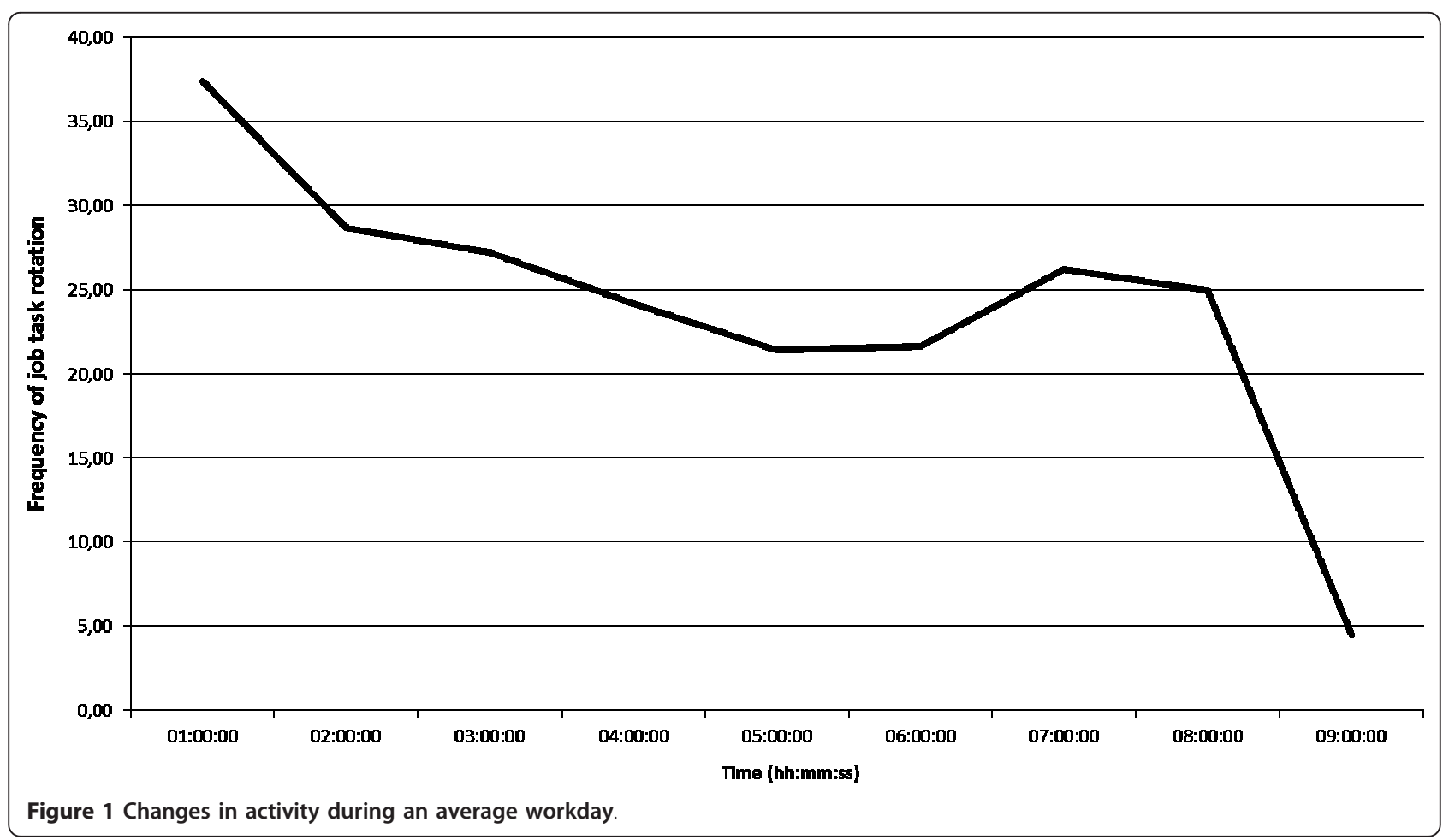


school teachers. Reason for this is the fact that the majority of educators are female in Germany. Therefore a focus should be set on male nursery school teachers in future investigations in order to assess gender differences in educators' work-loads.

Second, the number of participants monitored might be too small to be representative of all nursery school teachers. In the future, the present approach should be extended to a larger sample size. Additional studies are needed to replicate our findings in day care centres of different ownerships.

Third, the process of being observed might have influenced on the working behaviour of the educators (Hawthorne effect). Though it is too exhausting to adjust one' own work performance over a period of time. Therefore one can assume that observers' presence may not have a noteworthy effect on the general conclusions of the present investigation.

\section{Conclusion}

The current study is the first of its kind to investigate the workflow of pedagogical staff in a German day care centre and as such, provides a valuable basis for future studies. The study results substantiate educators' statements about their working conditions with regard to size of the group, which comes at the cost of direct child contact. In addition the impact of time pressure was confirmed and which resulted in multitasking. Future studies should also investigate the rate of interruptions during work shift as many educators complain about it.

\section{Acknowledgements}

This study was supported by the Institution for Statutory Accident Insurance in the Health and Welfare Services.

\section{Author details \\ ${ }^{1}$ Institute for Occupational, Social and Environmental Medicine, Theodor- Stern-Kai 7, 60590 Frankfurt am Main, Germany. ${ }^{2}$ Department of Respiratory Medicine, Hannover Medical School, Carl-Neuberg-Straße 1, 30625 Hannover, Germany. ${ }^{3}$ Department of Medicine/Psychosomatics, Charité - \\ Universitätsmedizin Berlin, Free University and Humboldt University, Luisenstraße 13a, 10117 Berlin, Germany. ${ }^{4}$ Institution for Statutory Accident Insurance in the Health and Welfare Services, Pappelallee 35/37, 22089 Hamburg, Germany.}

\section{Authors' contributions}

BK and SM conceived and designed the study. BK managed the data assessment. BK analysed the data. BK wrote the manuscript. BK, SM, DQ, AN and DAG contributed substantially to its final version. All authors read and approved the final manuscript.

\section{Competing interests}

The authors declare that they have no competing interests.

Received: 6 December 2011 Accepted: 22 December 2011 Published: 22 December 2011
References

1. Rudow B: Belastungen und der Arbeits- und Gesundheitsschutz bei Erzieherinnen. Langfassung des Projektberichtes. Mannheim \& Mühlhausen/Thür.: Institut für Gesundheit und Organisation (IGO); 2004.

2. Seibt $R$, Khan A: Netzwerk für gesunde Beschäftigte in Kindertagesstätten. Dresden: Institut Poliklinik für Arbeits- und Sozialmedizin; 2005

3. Schad M: Erziehung (k)ein Kinderspiel. Gefährdungen und Belastungen des pädagogischen Personals in Kindertagesstätten. Frankfurt am Main: Unfallkasse Hessen; 2002

4. Bamberg H: Kita- Alltag in Berlin. Soziale Arbeit 1995, 44:79-85.

5. Seibt R, Dutschke $D$, Thinschmidt $M, K$ A: Netzwerk für gesunde Beschäftigte in Kindertagesstätten-Projektkonzept, Umsetzung und erste Befunde. Zeitschrift Arbeit 2004, 3:312-319.

6. Rudow B: Arbeitsbedingungen für Erzieher/innen. Hohe psychische Belastungen. Bildung und Wissenschaft 2004, 6-13.

7. Botzet M, Frank H: Arbeit und Gesundheit von Mitarbeiterinnen in Kindertageseinrichtungen. Regionalfallstudie in saarländischen Kindertageseinrichtungen. Saarbrücken: Landesarbeitsgemeinschaft für Gesundheitsförderung e.V.; 1998.

8. Gewerkschaft Erziehung und Wissenschaft: Wie gehts im Job? KiTa-Studie der GEW. Frankfurt am Main: Gewerkschaft Erziehung und Wissenschaft Hauptvorstand; 2007.

9. Ulich E: Arbeitspsychologie Zürich: Schäffer-Poeschel; 2005.

10. Kusma B, Nienhaus A, Spallek M, Quarcoo D, Groneberg DA, Mache S: Bidirectional Assessment of Stress, job satisfaction and work ability of Educators in day care centres: a real-time observation study - the study protocol (BASE). J Occup Med Toxicol 2010, 5:16.

11. Mache S, Vitzthum K, Kusma B, Nienhaus A, Klapp BF, Groneberg DA: Pediatricians' working conditions in German hospitals: a real-time task analysis. Eur J Pediatr 2010, 169:551-555.

12. Mache S, Scutaru C, Vitzthum K, Gerber A, Quarcoo D, Welte T, Bauer T, Spallek M, Seidler A, Nienhaus A, et al: Development and evaluation of a computer-based medical work assessment programme. J Occup Med Toxicol 2008, 3:35.

13. Solzbacher C, Warnecke W: Individuelle Förderung in Kindertagesstätten: Begründungen, Ziele, Herausforderungen. In Kindergartenpädagogik Online-Handbuch Edited by: Textor MR 2009 [http://www. kindergartenpaedagogik.de/2005.html].

14. Ostermayer E: Bildung durch Beziehung - Wie Erzieherinnen den Entwicklungsund Lernprozess von Kindern fördern Freiburg im Breisgau: Herder; 2006.

15. Becker-Stoll F, Textor MR: Die Erzieherin-Kind-Beziehung Berlin: Cornelsen; 2007.

16. Bönsch M: Das Lehrer/in-Schüler/in-Verhältnis. In Pädagogik. Edited by: Roth L. München: Oldenburg-Verlag; 2001:898.

17. Kahle I: Die Elternarbeit als Bindeglied zwischen familialer und institutioneller Ökologie. In Ökologie des Kindergartens. Edited by: Dippelhofer-Stiem B, Wolf B. Weinheim: Juventa; 1997:49-76.

18. Mundt JW: Vorschulkinder und ihre Umwelt. Eine Studie über Lebensbedingungen und Entwicklungschancen Weinheim: Beltz; 1980.

19. Dusolt H: Elternarbeit. Ein Leitfaden für den Vor- und Grundschulbereich Weinheim: Beltz; 2001

20. Sturzbecher D, Bredow C: Das Zusammenwirken von Familie und Kita Voraussetzungen und Erfahrungen aus der Perspektive von drei Bundesländern. In Kinderbetreuung in Deutschland Bilanzen und Perspektiven. Edited by: Sturzbecher D. Freiburg: Lambertus; 1998:193-233.

21. Fried L, Dippelhofer-Stiem B, Honig M-S, Liegle L: Pädagogik der frühen Kindheit Weinheim: Beltz; 2003.

22. Cramer M, Förster A, Groß M, Mann H: „Was braucht die Kita zur Umsetzung des Sächsischen Bildungsplans?” Eine Untersuchung zum Abgleich von gesetzlich festgelegten Aufgaben und Zielen und den vorhandenen Personal - und Zeitressourcen in Sächsischen Kindertageseinrichtungen. Dresden: Paritätischer Wohlfahrtsverband Landesverband Sachsen e.V; 2007.

23. Brante G: Multitasking and synchronous work: Complexities in teacher work. Teach Teach Educ 2009, 25:430-436.

24. Nolting H-D, Berger J, Niemann D, Schiffhorst G, Genz HO, Kordt M: Stress bei Kindergärtner/innen. Hamburg: BGW; DAK; 2000.

25. Dippelhofer-Stiem B, Kahle I: Empirische Analysen zur pädagogischen Arbeit im Kindergarten. Zeitschrift für Frauenforschung 1994, 12:111-122. 
26. Kirsh D: A few thoughts on cognitive overload. Intellectia 2000, 1:19-51.

27. Rubinstein J, Meyer D, Evans J: Executive control of cognitive processes in task switching. J Exp Psychol 2001, 4:763-797.

28. Girard NJ: Multitasking: how much is too much? AORN J 2007, 85:505-506.

doi:10.1186/1745-6673-6-36

Cite this article as: Kusma et al:: Educators' working conditions in a day

care centre on ownership of a non-profit organization. Journal of

Occupational Medicine and Toxicology 2011 6:36.

Submit your next manuscript to BioMed Central and take full advantage of:

- Convenient online submission

- Thorough peer review

- No space constraints or color figure charges

- Immediate publication on acceptance

- Inclusion in PubMed, CAS, Scopus and Google Scholar

- Research which is freely available for redistribution

Submit your manuscript at www.biomedcentral.com/submit 